\title{
FURROW IRRIGATION MANAGEMENT AND DESIGN CRITERIA USING EFFICIENCY PARAMETERS AND SIMULATION MODELS
}

\author{
Eduardo A. Holzapfel ${ }^{1 *}$, Carlos Leiva ${ }^{1}$, Miguel A. Mariño ${ }^{2}$, Jerónimo Paredes ${ }^{1}$, José L. Arumí ${ }^{1}$, and \\ Max Billib ${ }^{3}$
}

\begin{abstract}
This study analyzes the relationship between the variables of furrow irrigation and the irrigation performance parameters, crop yield, and deep percolation as a basis for furrow irrigation design and management. Application efficiency (AE), requirement efficiency (RE), requirement distribution efficiency (RDE), total distribution efficiency (TDE), and furrow irrigation management, operation, and design variables (inflow discharge, furrow length, and irrigation cutoff time) were correlated. The relationship between performance irrigation parameters and relative yield was also examined. In addition, environmental aspects related to leaching and runoff were also presented for each of the parameters. Study results indicate that increasing the length of the furrow reduces RE, RDE, and TDE values. However, an increase in inflow discharge and cutoff time increases efficiency. In contrast, an increase in furrow length increases $\mathrm{AE}$ while an increase in inflow discharge and cutoff time reduces it. Unlike AE, RE, RDE, and TDE parameters are well-correlated with relative yield. TDE and AE are recommended parameters for the design, management, and operation of furrow irrigation systems, in order to establish good irrigation practices, and to prevent contamination.
\end{abstract}

Key words: furrow, irrigation, performance parameters, model, yield, leaching.

\section{INTRODUCTION}

Optimum management of water resources at the farmlevel is needed in view of increasing water demands, limited resources, and aquifer contamination (Kumar and Singh, 2003).

When irrigation is required there are many available methods and management strategies. The selection of the method and approach depends on factors such as water availability, crop type, soil characteristics, land topography, and associated cost (Holzapfel y Arumí, 2010). During the past two decades, surface irrigation have become available, in which procedures and criteria have been established for the optimum design and efficient management and operation of the water applied to crops to obtain maximum yield and avoid environmental

${ }^{1}$ Universidad de Concepción, Facultad de Ingeniería Agrícola, Casilla 537, Chillán, Chile.*Corresponding author (eholzapf@udec.cl).

${ }^{2}$ University of California, Hydrologic Sciences and Civil and Environmental Engineering, Davis, California, 95616, USA.

${ }^{3}$ Gottfried Wilhelm Leibniz University of Hannover, Institute of Water Resources Management, Hydrology and Agricultural Hydraulic Engineering, Appelstr. 9a, D-30167, Hannover, Germany. Received: 30 April 2009.

Accepted: 11 September 2009. contamination of soil and groundwater due to leaching and runoff.

Intensive irrigated agriculture involves water application, fertilizers, and other chemicals applied in varying amounts to the annual cropped and orchard areas. Yet, as in any enhanced productive activity, irrigated agriculture can lead to environmental contamination if it is improperly managed. When utilization of these chemicals is incomplete or inefficient, or when water is applied in excess, the resultant runoff and seepage ultimately ends up in drainage systems or in recharging aquifers beneath the cropped land (Hadas et al., 1999).

The amounts of applied water and resulting leachate vary with the type of irrigation system used, irrigation efficiency, crop or orchard utilization of water and fertilizers, the composition of the added organic materials, and absorption and decomposition of the chemical of interest. Nitrate is the dominant anion, derived from fertilizers and decomposing organic materials. In addition, pesticides and other chemicals are incorporated in the irrigation; the leaching of pesticides and their breakdown products increases in direct relation with an increase in the amount of percolating water produced by irrigation (Asare et al., 2001). The close association between leaching and 
amount of deep-percolating water produced by irrigation is expected because leaching occurs through dissolution of solute in soil solution and subsequent movement with soil water (Troiano et al., 1993). Pesticides in California ground water have been found in a variety of diverse climatic and soil conditions, including semiarid, intensively-irrigated, and coarse soil areas with shallow depth to ground-water (Spurlock, 2000). Efficient irrigation practices that minimize deep percolation will therefore minimize leaching of contaminants. Thus, it is important to use adequate irrigation systems and management techniques to reduce chemical leaching by decreasing deep percolation.

The most frequently used surface irrigation methods in the world are contour irrigation, border irrigation, and furrow irrigation (Walker and Skogerboe, 1987). The latter is used mainly to irrigate row crops and orchards. Most recently, furrow irrigation has become important because of the high cost of energy in pressurized irrigation methods and the incorporation of automation in its operation (Holzapfel and Arumí, 2010). In general, furrow irrigation is characterized by four phases: advance, storage, depletion, and recession (Walker and Skogerboe, 1987). The difference in time between the advance and recession phases is known as irrigation opportunity time.

Numerical simulation techniques are common for irrigation analysis and were successfully applied to simulate steady and unsteady flow with solute transport in furrow irrigation (Burguete et al., 2009a). Surface irrigation are characterized by their operation simplicity; however, design and management are complicated (Burguete et al., 2009b). Several mathematical models have been proposed to simulate the advance front of the irrigation water (Souza, 1981). Some of those models have been implemented to simulate the advance phase in furrow irrigation. Holzapfel et al. (1984) showed that the kinematic-wave and volume-balance models closely predicted the advance and recession phases.

In furrow irrigation in clayey soil, Eldeiry et al. (2004) found that furrow length and application discharge are the main management and design parameters affecting application efficiency. The environmental impact of furrow irrigation has been reported by Lehrsch et al. (2000). Popova et al. (2005) found that in irrigation, a risk of nitrate leaching depends on the manner of water and fertilizer application. Lazarovitch et al. (2009) study of the moment analysis technique describes spatial and temporal subsurface wetting patterns resulting from furrow infiltration and redistribution that contribute to improve irrigation management. In many irrigated regions of the western United States, commercial growers that irrigate by furrow irrigation systems are facing serious challenges to improve irrigation efficiency and reduce contamination of water supplies (Rice et al., 2001).

For the long term sustainability of an irrigation system, improvements in the performance of current water application and on-farm water management practices seem to be more necessary than any other practice (Sarwar et al., 2001). To increase the sustainability of irrigated agriculture, an important aspect that has been considered in several studies is to design efficient irrigation systems at the farm-level (Feyen and Zerihun, 1999; Zerihun et al., 2001; Hillel and Vlek, 2005; Khan et al., 2006; Hsiao et al., 2007). The irrigation efficiency is a crucial aspect for irrigated agriculture and a key factor due to the competition for water resources. In the case of furrow irrigation, the most important points are to adequately select furrow irrigation variables (furrow length, time of cutoff, and discharge), improve irrigation scheduling, and improve water management of the field which will also potentially reduce over-irrigation and deep percolation of applied water and chemicals.

The purpose of this paper was to analyze furrow irrigation variables (inflow discharge, furrow length, and time of irrigation cutoff) and their relation to performance irrigation parameters and crop production, as well as to deep percolation, which affects soil and water contamination. Herein, volume-balance irrigation models with a recession phase developed by Holzapfel et al. (1984) were used to simulate the furrow irrigation process.

\section{Models to determine performance of irrigation}

The performance of an irrigation method can be evaluated by determining how well the irrigation meets the water requirements and how well the applied water is distributed throughout the field (Holzapfel et al., 1985). Water applied for irrigation should: (1) meet the plant water requirements at the time of irrigation; (2) not exceed the available water-storage capacity of the soil profile; (3) avoid leaching in excess of that required to prevent soil salinization and excessive runoff; and (4) minimize erosion and deterioration of the soil structure. The performance of an irrigation method is affected by: rate of infiltration of water into the soil; inflow rate of the water; slope of the field; time of irrigation; time of recession of water from the soil surface; soil moisture prior to irrigation; spatial variability of the soil; climatic conditions; and furrow shape. The performance of irrigation parameters have been analyzed by various researchers (Holzapfel et al., 1985; Heermann et al., 1990; Burt et al., 1997; Hsiao et al., 2007). However, problems have been encountered in the effective evaluation of the performance of an irrigation method, owing to difficulties in identifying inadequacies in operation, management or design (Feyen and Zerihun, 1999). Irrigation performance can mainly be 
determined by using conjunctively various parameters, because one is not capable to describe if the irrigation has satisfied the plant water requirements and environmental effects. In this study, we analyze four parameters to estimate irrigation performance: application efficiency, requirement efficiency, requirement distribution efficiency, and total distribution efficiency.

\section{Application efficiency}

Zerihun et al. (2001) defined water application efficiency (AE) as the ratio between the volume of water held in the root zone of the soil profile after the irrigation and the total volume of water applied during the irrigation process:

$$
\mathrm{AE}=\frac{\int_{0}^{L} Z d x-\int_{0}^{L u} Z d x+Z_{r} L_{u}}{C u \int_{0}^{t_{c o}} Q_{0} d t} * 100
$$

in which $L$ is the furrow length (m); $Z_{r}$ is the volume of water required by the crop in each irrigation and is obtained from the irrigation schedule $\left(\mathrm{m}^{3} \mathrm{~m}^{-1}\right) ; L_{u}$ is the length of the furrow reach over which the infiltrated water amount equals or exceeds $Z_{r}\left(\mathrm{~m}^{3} \mathrm{~m}^{-1}\right) ; C u$ is a unit conversion factor $\left(10^{-3} \mathrm{~m}^{3} \mathrm{~L}^{-1}\right) ; Q_{0}$ is the inlet flow rate $(\mathrm{L}$ $\left.\min ^{-1}\right) ; t_{c o}$ is the cutoff time of the irrigation (min); and $\mathrm{Z}$ is the amount of infiltrated water $\left(\mathrm{m}^{3} \mathrm{~m}^{-1}\right)$.

\section{Requirement efficiency}

The requirement efficiency or water storage efficiency (RE) measures the effectiveness of the quantity of water stored in the root zone after the irrigation (Zerihun et al., 2001):

$$
\mathrm{RE}=\frac{\int_{0}^{L} Z d x-\int_{0}^{L u} Z d x+Z_{r} L_{u}}{Z_{r} L} * 100
$$

\section{Requirement distribution efficiency}

The requirement distribution efficiency (RDE) measures the effects of the distribution of applied water in relation with crop water requirements (Holzapfel et al., 1985) and assumes that the crop yield is not affected seriously by the excess of applied water. It can be expressed mathematically as:

$$
R D E=1-\left[\frac{\sum_{i=1}^{w}\left|Z_{i}-Z_{r}\right|}{n \cdot Z_{r}}\right] * 100 \quad \text { for } Z_{i} \leq Z_{r}
$$

in which $Z_{i}$ is the depth of water infiltrated at point $\mathrm{i}$ (m); $Z_{r}$ is the depth of water required by the crop in each irrigation and is obtained from the irrigation schedule $\left(\mathrm{m}^{3}\right.$ $\left.\mathrm{m}^{-1}\right) ; w$ is the number of observations in which $Z_{i}$ is less than or equal to $Z_{r}$; and $n$ the total number of observations.

\section{Total distribution efficiency}

Total distribution efficiency (TDE) describes the distribution of the applied water in relation with crop water requirements, taking into account deficits and excesses (Holzapfel et al., 1985). It can be defined as:

$$
T D E=\left[1 \frac{\sum_{i=1}^{n}\left|Z_{i}-Z_{r}\right|}{n \cdot Z_{r}}\right] * 100
$$

The concepts expressed by Equations [3] and [4] are based on deviations from the depth of water required by the crops, indicating that as the depth of water applied is approximately equal to the depth of water required throughout the field, the better the performance of the irrigation. In addition, TDE may show some effect of excess applied water on yield and relatively the effect of leaching and contamination to clean irrigation. This performance parameter has been tested in an orchard and crops by Holzapfel et al. (1985) and in the irrigation project Fondef D02I-1146 (Holzapfel and Arumí, 2010).

\section{MATERIALS AND METHODS}

To study the operation, management and design process in furrow irrigation and establish relations between the variables and performance irrigation parameters, 300 simulations were made with a volume-balance model developed by Holzapfel et al. (1984), previously tested at a field in Chillán, Chile. Table 1 shows the basic data used in the process described in this paper for a volcanic ash derived soil and cropped in double-row sugar beets (Beta vulgaris L. subsp. vulgaris) with a furrow spacing of 1 $\mathrm{m}$. The Kostiakov-Lewis cumulative infiltration equation was used to describe the infiltration process for this type of soil on the basis of previous studies (Holzapfel et al., 1984; 1988). The simulations were generated through a combination of different values of the furrow irrigation variables (inflow discharge, length of furrow, and cutoff time), to obtain a wide range of variation in parameter values. The performance irrigation parameters used were AE, RE, RDE, and TDE. Those were selected on the basis of previous work (Holzapfel et al., 1985) and an analysis of performance of the parameters in other studies (Ibarra, 2004; Becerra and Hermann, 2006; Hsiao et al., 2007). Subsequently, an analysis was performed to develop a mathematical function that could relate furrow irrigation variables with each of the performance irrigation parameters. 
Table 1. Parameters needed and data required by the volume-balance model for furrow irrigation.

\begin{tabular}{|c|c|c|}
\hline Parameter & Value & Unit \\
\hline \multicolumn{3}{|c|}{ Equation of cumulative infiltration } \\
\hline Constant K & 0.00449 & $\mathrm{~m}^{3} \min ^{-\mathrm{N}} \mathrm{m}^{-1}$ \\
\hline Constant $\mathrm{N}$ & 0.55000 & Dimensionless \\
\hline Constant $\mathrm{F}_{\mathrm{o}}$ & 0.00000 & $\mathrm{~m}^{3} \min ^{-1}$ \\
\hline \multicolumn{3}{|l|}{ Furrow shape factors } \\
\hline $\mathrm{C}_{1}$ & 9.06200 & Dimensionless \\
\hline $\mathrm{C}_{2}$ & 2.21300 & Dimensionless \\
\hline $\mathrm{A}_{1}$ & 0.09100 & Dimensionless \\
\hline $\mathrm{A}_{2}$ & 2.61000 & Dimensionless \\
\hline Inflow discharge & $0.08-0.17$ & $\mathrm{~m}^{3} \min ^{-1}$ \\
\hline Cutback inflow & 0.04-0.085 & $\mathrm{m}^{3} \min ^{-1}$ \\
\hline $\begin{array}{l}\text { Manning roughness } \\
\text { coefficient }\end{array}$ & 0.0300 & Dimensionless \\
\hline Slope & 0.00550 & $\mathrm{~m} \mathrm{~m}^{-1}$ \\
\hline Time increment & 1.00 & $\min$ \\
\hline Time of cutoff & $60-155$ & $\min$ \\
\hline $\begin{array}{l}\text { Distance between } \\
\text { furrows }\end{array}$ & 1.00 & $\mathrm{~m}$ \\
\hline Furrow length & $70-190$ & $\mathrm{~m}$ \\
\hline Water requirement & 0.0547 & $\mathrm{~m}$ \\
\hline
\end{tabular}

To study the relation between the performance irrigation parameters and relative yield, a computer program (written in $\mathrm{C}^{++}$) was developed based on the results of the simulation program and the incorporation of a relative water production function, which calculated yield with respect to the maximum potential yield that can be attained by that irrigation condition. A schematic representation of the process is presented in Figure 1. Fifty different scenarios were analyzed using the aforementioned computer program. Each of the scenarios had a value associated with each performance irrigation parameter, which made possible the development of a relation between those performance parameters and relative yield.

The water production-relative yield relation used in this study was approximated by a second-order polynomial (Campos, 2003). It can be expressed as

$$
P R=A_{c} \cdot(E T R)^{a}+B_{c} \cdot(E T R)^{b}+C_{c}
$$

in which $\mathrm{PR}=\mathrm{P} / \mathrm{PM}$ and $\mathrm{ETR}=\mathrm{ET}_{\mathrm{a}} / \mathrm{ETM}$ where, $P$ is observed production; $P M$ is maximum production; $P R$ is relative production; $E T_{a}$ is actual evapotranspiration; $E T M$ is maximum or required evapotranspiration; ETR is relative evapotranspiration; and $a, b, A_{c}, B_{c}$, and $C_{c}$ are regression coefficients. ETM was assumed to be the maximum evapotranspiration expected during the irrigation season with an $85 \%$ probability, while $\mathrm{ET}_{\mathrm{a}}$ was estimated as the weighted average depth of the infiltrated water along the furrow, on the basis of water requirements. Table 2 shows the coefficients of the water production-relative yield function for sugar beet used in this study. Subsequently, functions were examined that could relate the relative yield with each one of the performance irrigation parameters described earlier (AE, RE, RDE, and TDE). The regression analysis was made by using the method of minimum squares (Chapra and Canale, 1996). The analysis was carried out in two parts: first, by using multiple linear regression, and second, by polynomial regression. To determine the goodness-of-fit

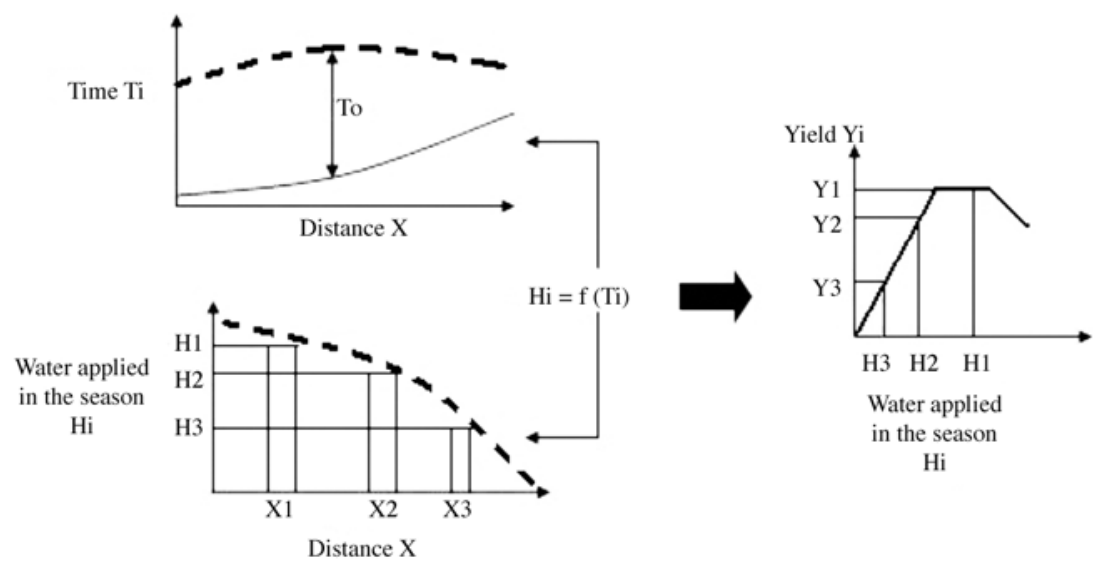

Figure 1. Graphical representation for the analysis of surface irrigation systems considering management and design processes. 
Table 2. Values of coefficients of the water productionrelative yield function for sugar beet (Equation [5]).

\begin{tabular}{lc}
\hline Coefficient & Value \\
\hline $\mathrm{A}_{\mathrm{c}}$ & -1.307 \\
$\mathrm{~B}_{\mathrm{c}}$ & 2.710 \\
$\mathrm{C}_{\mathrm{c}}$ & -0.394 \\
$\mathrm{a}$ & 2.000 \\
$\mathrm{~b}$ & 1.000 \\
\hline
\end{tabular}

$\mathrm{A}_{\mathrm{c}}, \mathrm{B}_{\mathrm{c}}, \mathrm{C}_{\mathrm{c}}, \mathrm{a}, \mathrm{b}$ : Regression coefficients.

of the resulting relations, the statistical test of coefficient of determination (Scheaffer and McClave, 1993) was applied to the equations obtained by both multiple linear regression and polynomial regression.

\section{RESULTS AND DISCUSSION}

Multiple linear regression (Chapra and Canale, 1996) was used to relate the furrow irrigation variables with the performance irrigation parameters (AE, RE, RDE, and TDE). The regression equation obtained corresponds to an exponential function and has the form:

$$
(M C R)_{i}=(K)_{i} \cdot(Q)^{a_{i}} \cdot(L)^{b_{i}} \cdot\left(T_{c o}\right)^{c_{i}}, i=1, \ldots, 4
$$

where $M C R_{i}$ is the performance irrigation parameter i; $K_{i}$ is the constant of the exponential equation of the parameter $\mathrm{i} ; a_{i}, b_{i}, c_{i}$ are the exponential coefficients for the inflow, furrow length, and cutoff time, respectively, in the performance irrigation model i; $Q$ is the inflow, $L$ is the furrow length, and $T_{C O}$ is the time of cutoff.

In general, a good correlation was obtained among performance irrigation parameters and the design or management variables for furrow irrigation. Water application efficiency was the model that had the best correlation with the furrow irrigation variables as was obtained by Zerihun et al. (2001) for a fixed given value of requirement efficiency. The exponential equation, with a determination coefficient $\mathrm{R}^{2}$ of 0.982 , for this performance irrigation model is:

$$
A E=17.715624 \cdot Q^{-0.42332} \cdot L^{0.456306} \cdot T_{C O}{ }^{-0.343620}
$$

Equation [7] shows that water application efficiency increases its value while the furrow length is increased, whereas its value decreases when either the inflow or cutoff time increases. Thus, it can be deduced that a furrow irrigation using a large inflow, a small furrow length, and a long cutoff time losses more water than using a large furrow length, a small inflow, and a small cutoff time. In other words, the volume of water held in the root zone does not increase at the same rate as the volume of applied water. The AE does not take into account the uniformity of the applied water nor the level of water required by the crop. AE only estimates the percentage of applied water stored in the root zone. However, it is an important performance parameter for evaluating leaching and runoff, and determining the effect of irrigation in the contamination of soil, surface water, and groundwater.

Requirement efficiency was well correlated with the design variables through the exponential relation with a determination coefficient $R^{2}$ of 0.902 . The regression equation has the form:

$$
R E=26.19527 \cdot Q^{0.139828} \cdot L^{-0.084872} \cdot T_{C O}^{0.437575}
$$

Equation [8] indicates that RE increases its value with an increase in both inflow and cutoff time and a decrease in furrow length. Throughout the study, it was observed that a variation in the cutoff time affects more significantly the RE than does the inflow or furrow length. This was reflected in the values of the coefficients for each design variable, that is, $\left|c_{i}\right|>\left|a_{i}\right|>\left|b_{i}\right|$. Thus, in general, for requirement efficiency it is more important to have reliable estimates of both crop requirements and irrigation times than precise estimates of inflows. This parameter does not pay attention to the leaching and runoff that may affect contamination due to the irrigation process.

Requirement distribution efficiency is well correlated to the furrow irrigation variables through the exponential equation with a determination coefficient $R^{2}$ of 0.863 :

$$
R D E=31.083153 \cdot Q^{0.206051} \cdot L^{-0.132540} \cdot T_{C O}^{0.477585}
$$

Similar to RE, values of RDE increase with increasing inflow and cutoff time, and decrease with an increase in furrow length. The relation among the exponential coefficients was $\left|c_{i}\right|>\left|a_{i}\right|>\left|b_{i}\right|$, showing again that variations in cutoff time have a greater influence on the value of RDE than either the inflow or the furrow length. Thus, if the objective is to satisfy the water needs of a crop in such a way that each area receives the requirement, then it is more important to control accurately the cutoff time than the other variables. Also, RDE does not consider the effects of losses of applied water.

Total distribution efficiency correlated well with the furrow irrigation variables given a determination coefficient $\mathrm{R}^{2}$ of 0.759 . The exponential correlation equation was:

$$
T D E=44.447201 \cdot Q^{0.214309} \cdot L^{-0,138887} \cdot T_{C O}{ }^{-0.405306}
$$

The relation between the design variables and TDE was similar to that observed for RE and RDE. In all these cases, the relation between the coefficients of the exponential 
equations was $\left|c_{i}\right|>\left|a_{i}\right|>\left|b_{i}\right|$, showing that the variation in cutoff time is more important in the determination of the value of the performance irrigation parameter than the variation of the inflow and furrow length. Indeed, during the design and operation process it was observed that for each unit increase in cutoff time, a larger volume of water entered the furrow than if the discharge were increased by the same rate. Hence, the time of irrigation cutoff is the most important variable in furrow irrigation when the objective is to maximize irrigation efficiency. Similar results were obtained by Holzapfel et al. (1986) under optimum surface irrigation design, using optimization process and Zerihun et al. (2001) to design and management furrow irrigation under a fix RE value. Based on the results discussed earlier and on the analysis of the adequacy of each parameter to reflect the behaviour of the irrigation, it can be said that RE, RDE, and TDE are the parameters that give the best performance of the irrigation as a function of the water requirements of a furrow-irrigated crop and TDE and AE give a better description of the leaching and contamination effects of the furrow irrigation.

\section{Relation between the performance irrigation parameters, relative yield, and deep percolation}

Successive analysis, using the computer program previously mentioned, showed that a second-order polynomial regression is a good predictor of performance irrigation parameters and relative crop yield. As a result, we found three expressions that describe the relation between RE, RDE, and TDE with the relative crop yield.

For AE it was not possible to find any relation because this parameter is unable to account for crop yield changes. Figure 2 clearly indicates the lack of a relationship between $\mathrm{AE}$ and crop production. This is because there is no relation between $\mathrm{AE}$ and crop water requirements and/or uniformity of the applied water. In fact, it is possible to store the total amount of applied water in the root zone without supplying the crop requirements, and obtaining AE levels near 100\%. Similar values can be also obtained by applying the entire amount of water to the crop, without considering an equitable distribution of the applied water. In contrast, RE, RDE, and TDE showed an excellent correlation with crop production.

Equations that govern performance irrigation parameters with relative crop yield have the general form:

$$
(R Y)=M_{i} \cdot(M C R)_{i}^{2}+N_{i} \cdot(M C R)_{i}+O_{i} \quad i=1,2,3
$$

where RY is relative yield in percentage and $M_{i}, N_{i}$, and $O_{i}$ are the regression coefficients for the second-order polynomial performance irrigation model i. Table 3 shows the values of $M, N, O$, and $R^{2}$ for each one of the performance irrigation parameters.

Figure 3 shows the relation between RE and RY. It can be seen that RE is well correlated to crop production. This agrees with the fact that by satisfying the crop water requirements, higher production levels can be attained. However, RE does not reflect the over-application of water, which may have an important effect in diffuse groundwater contamination. In fact, it is possible to apply more water than is required and thus satisfy the water requirements of a crop. In these cases, $R E$ would still reach a value near $100 \%$. This is because RE only considers crop water requirements, and when those are satisfied, its value reaches equilibrium. Hence, RE can only reflect changes in crop production until the latter reaches a maximum and not account for the effect of excess water on yield and associated contamination problems. In addition this parameter could be important, under conditions described by Evans and Sadler (2008), as water shortages or the need for deficit irrigation management strategies induced by increased costs of inputs such as electricity, labor or combinations of external factors.

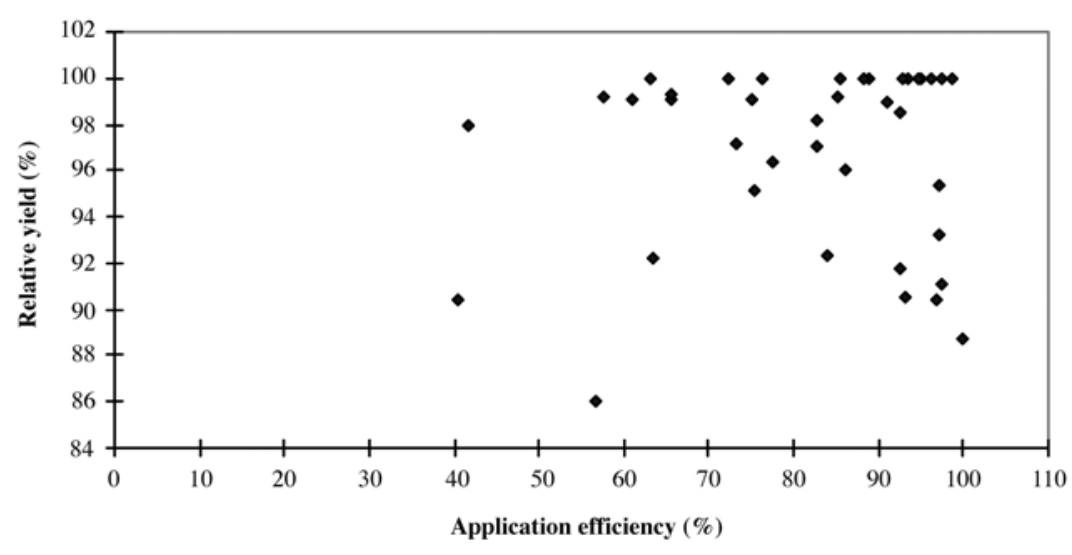

Figure 2. Relationship between application efficiency and relative yield. 
Table 3. Regression and correlation coefficients for performance irrigation parameters with respect to relative yield (Equation [11]).

\begin{tabular}{lcccc}
\hline $\begin{array}{l}\text { Performance } \\
\text { irrigation model }\end{array}$ & $\mathbf{M}$ & $\mathbf{N}$ & $\mathbf{O}$ & $\mathbf{R}^{\mathbf{2}}$ \\
\hline $\mathrm{RE}$ & -0.0223 & 4.3328 & -110.84 & 96.94 \\
$\mathrm{RDE}$ & -0.0207 & 3.9337 & -87.006 & 86.88 \\
$\mathrm{TDE}$ & -0.0127 & 2.5619 & -28.82 & 80.36 \\
\hline
\end{tabular}

RE: requirement efficiency; RDE: requirement distribution efficiency; TDE: total distribution efficiency.

M, N, O: Regression coefficients for the second-order polynomial.

Figure 4 shows the relation between RDE and RY. It can be observed that while the irrigation satisfies the crop water requirement, it is possible to reach greater crop productions. RDE has the same disadvantages as RE in explaining crop production and the contamination effect when there is an over-application of water. RDE gives an estimation of the irrigated area that has not received the required amount of water; thus, it does not reflect changes in crop production when the applied water exceeds crop water requirements. Hence, in over-application of water situations, it is possible for RDE to reach a value near $100 \%$, but never exceeding that value.

Figure 5 shows the relation between TDE and RY.
It can be observed that as the irrigation is more uniform and meets the crop water requirement, crop production increases. Unlike RE and RDE, TDE allows one to explain crop production when there is an over-application of water. Recall, that when large quantities of water are applied, the volume of infiltrated water increases, exceeding the crop water requirement, and thus producing an inadequate irrigation. This in turn provokes a decrease in TDE, similar to that observed when insufficient water is applied to satisfy the crop requirement, thus producing a so-called deficit irrigation. Recall also that plants obtain nutrients from the soil as well as from gases in the pores of the soil. Thus, when the soil profile is saturated and the

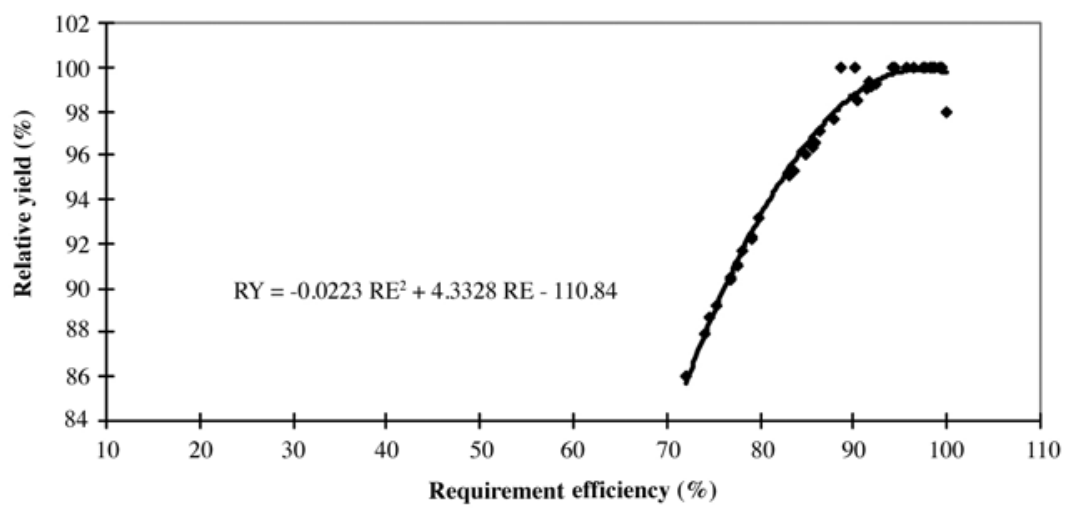

Figure 3. Relationship between requirement efficiency (RE) and relative yield (RY).

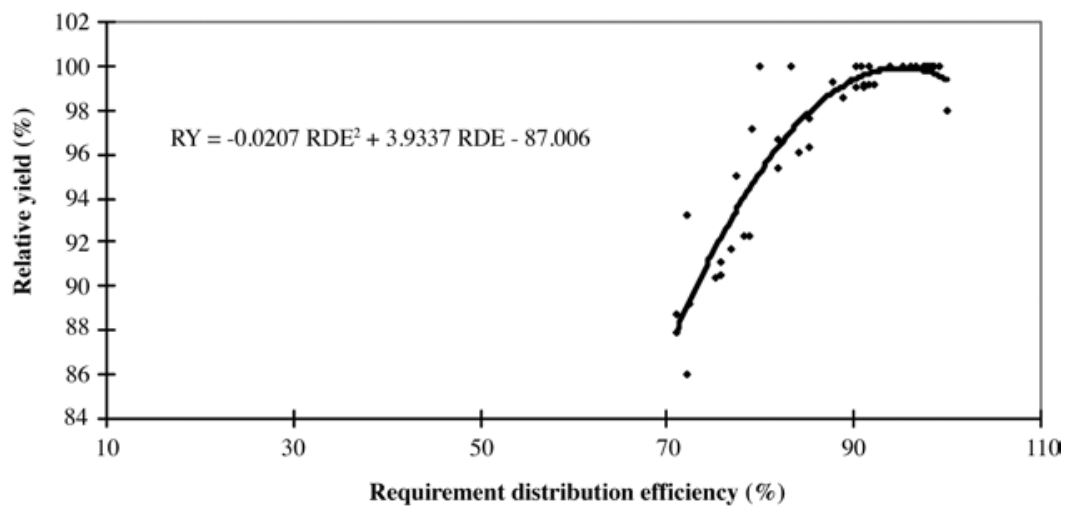

Figure 4. Relationship between requirement distribution efficiency (RDE) and relative yield (RY). 


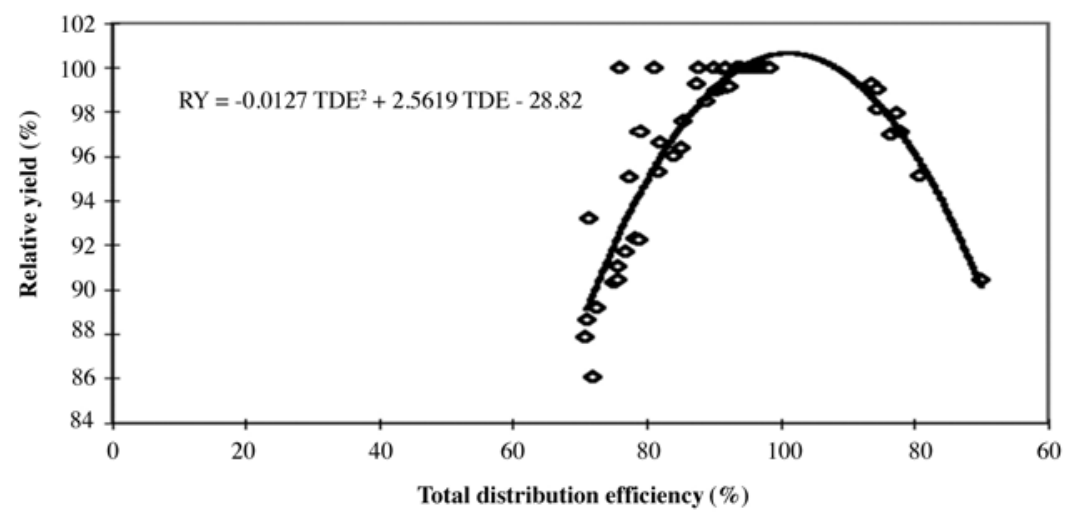

Figure 5. Relationship between total distribution efficiency (TDE) and relative yield (RY).

pore space is filled with water, it is extremely difficult for crops to obtain nutrients necessary for their growth and development, causing root asphyxiation. If the latter is temporary, then there would be a decrease in the crop's growth and thus a decrease in yield. On the other hand, if the asphyxiation is prolonged, it can cause the death of the crop and thus considerable production losses. To a large extent, TDE indicates yield behavior for a specified irrigation condition.

To develop a mathematical expression relating TDE with changes in production, values of TDE obtained in cases of over-application of water were transformed by using the equation:

$$
T D E_{e}=200-T D E_{o}
$$

where $T D E_{e}$ is the value of TDE from the relation of TDE vs. RY, and $T D E_{o}$ is the observed value of TDE. The proper use of Equation [12] requires the transformation of the values of TDE obtained in irrigation with an overapplication of water. In such case the TDE function was defined in two steps for the deficit and excess of water application, due that water application over the maximum value of relative yield, reduce the yield as it is shown in the following equations:

$$
P R_{d}=-0.0127(T E D)^{2}+2.5619(T E D)-28.82
$$

$P R_{e}=-0.0127(200-T E D)^{2}+2.5619(200-T E D)-28.82[14]$

where $\mathrm{PR}_{\mathrm{d}}$ is relative yield under deficit conditions and $\mathrm{PR}_{\mathrm{e}}$ is the relative yield under excess of water application. We assume in this study that the excess of water has the same effect as water deficit in crop yield, taking into account loss of nutrients, root asphyxiation, and reduction in root water extraction.

An analysis of the management, operation, and design process indicated that over-application of water is related with small furrow lengths, larger inflows, and/or long cutoff times (greater than those necessary for obtaining an optimal irrigation). Clearly, choosing the wrong values of the furrow irrigation variables produces an over-use of water and thus a loss in crop production and a detrimental effect on surface water and groundwater quality due to leaching and runoff.

On the basis of the aforementioned discussion for the management, operation, and design of furrow irrigation, one can use the parameters RE, RDE, and TDE. Furthermore, TDE with AE can be used to consider water contamination effects. Based on conditions specified in this study, TDE has the capability to relate the performance of the irrigation and crop production and may show the contamination risk with the excess of water application.

\section{CONCLUSIONS}

Requirement efficiency, requirement distribution efficiency, and total distribution efficiency are the performance irrigation parameters that correlate best with furrow irrigation variables (inflow discharge, furrow length, and time of irrigation cutoff) and can be used for design, management, and operation of furrow irrigation systems. They are also the parameters that correlated best with crop yield, thus serving as a linkage between yield and the irrigation variables. In contrast, the application efficiency correlated well with the design variables but not with yield; however, it is the most important parameter to use when evaluating deep percolation and contamination of irrigation in soil, surface water, and groundwater. Furthermore, the total distribution efficiency is the performance irrigation parameter that can express conditions of either deficit or over-application of water in furrow irrigation. Thus, TDE and AE are recommended to be used for the design, management, and operation of furrow irrigation systems, to establish 
good irrigation practices, and to prevent contamination and environmental problems associated with irrigation.

\section{ACKNOWLEDGEMENT}

The research reported in this paper was conducted at the Department of Water Resources of the Universidad of Concepción, Chillán, Chile, as part of FONDEF Projects D02I-1146 and BMBF-CONICYT CHL/06/008/066 4. The revision of anonymous reviewers is recognized.

\section{RESUMEN}

Criterios para manejo y diseño de riego por surcos utilizando parámetros de eficiencia y modelos de simulación. El presente artículo analiza la relación entre las variables de riego por surcos y los parámetros que determinan la calidad del riego, producción, y percolación profunda como base para el diseño y manejo del riego por surcos. Se ha realizado la correlación entre la eficiencia de aplicación (AE), eficiencia de requerimiento (RE), eficiencia de distribución del requerimiento (RDE), eficiencia de distribución total (TDE), y las variables de manejo, operación y diseño de riego por surcos (caudal, longitud de surco y tiempo de corte de riego). También se ha examinado la relación entre los parámetros que determinan la calidad de riego y la producción relativa. Además, se presentan para cada uno de los parámetros anteriores aspectos medioambientales relacionados con percolación y escorrentía. Los resultados de este estudio indican que un aumento en la longitud del surco reduce los valores de RE, RDE, y TDE. Sin embargo, un aumento en el caudal y el tiempo de corte produce un incremento en dichas eficiencias. Por el contrario, un incremento en la longitud del surco aumenta el valor de la $\mathrm{AE}$, mientras que un aumento en el caudal y el tiempo de corte lo reduce. A diferencia de $\mathrm{AE}$, los parámetros RE, RDE, y TDE tienen una buena correlación con la producción relativa. TDE y AE son los parámetros recomendados para ser usados en diseño, manejo y operación de sistemas de riego por surco, para establecer buenas prácticas de riego y prevenir contaminación.

Palabras clave: surco, riego, parámetros de calidad, modelos, producción, percolación.

\section{LITERATURE CITED}

Asare, D.K., T. Sammis, D. Smeal, H. Zhang, and D.O. Sitze. 2001. Modelling an irrigation strategy for minimizing the leaching of atrazine. Agr. Water Manage. 48:225-238.

Becerra, A., and T. Hermann. 2006. Hydraulic simulation software of the irrigation by furrows using the kinematics wave model (Part I. Theoretical foundation). Dyna 73(149):107-117.
Burguete J., N. Zapata, P. García-Navarro, M. Maikaka, E. Playan, and J. Murillo. 2009a. Fertigation in furrow and level furrow system. I. Model description and numerical tests J. Irrig. Drain. Eng. ASCE 135:401412.

Burguete J., N. Zapata, P. García-Navarro, M. Maikaka, E. Playan, and J. Murillo. 2009b. Fertigation in furrow and level furrow system. II. Model calibration, and practical application. J. Irrig. Drain. Eng. ASCE 135:413-420.

Burt, C., T. Clemmens, T. Strelkoff, K. Solomon, L. Hardy, T. Howell, et al. 1997. Irrigation performance measure-efficiency and uniformity. J. Irrig. Drain. Div. ASCE 123:423-442.

Campos, J. 2003. Manejo de agua en remolacha bajo riego por cinta de goteo. $125 \mathrm{p}$. Tesis Ingeniero Civil Agrícola. Universidad de Concepción, Facultad de Ingeniería Agrícola, Chillán, Chile.

Chapra, S.C., y R.P. Canale. 1996. Métodos numéricos para ingenieros. 305 p. McGraw-Hill/Interamericana de México, México, D.F., México.

Eldeiry, A., L. García, H. El-Zaher, and M. Kiwan. 2004. Furrow irrigation system design for clay soils in arid regions. Hydrology Days 42-53.

Evans, R., and E.J. Sadler. 2008. Methods and technologies to improve efficiency of water use. Water Resour. Res. 44:1-15.

Feyen, J., and D. Zerihun. 1999. Assessment of the performance of border and furrow irrigation systems and the relationship between performance indicators and system variables. Agr. Water Manage. 40:353-362.

Hadas, A., B. Sagiv, and N. Haruvy. 1999. Agricultural practices, soil fertility management modes and resultant nitrogen leaching rates under semi-arid conditions. Agr. Water Manage. 42:81-95.

Heermann, D., W. Wallander, and M. Bos. 1990. Irrigation efficiency and uniformity. In Hoffman, G., T.A. Howell, and K. Solomon (eds.) Management of farm irrigation systems. American Society of Agricultural Engineers (ASAE), St Joseph, Michigan, USA.

Hillel, D., and P. Vlek. 2005. The sustainability of irrigation. Adv. Agron. 87:55-84.

Holzapfel, E.A., y J.L. Arumi (eds.) 2010. Tecnología de manejo de aguas para una agricultura intensiva sustentable. 209 p. Editorial Universidad de Concepción, Concepción, Chile (In press).

Holzapfel, E.A., M.A. Mariño, and J. Chávez-Morales. 1984. Comparison and selection of furrow irrigation models. Agr. Water Manage. 9:105-125.

Holzapfel, E.A., M.A. Mariño, and J. Chávez-Morales. 1985. Performance irrigation parameters and their relationship to surface-irrigation design variables and yield. Agr. Water Manage. 10:159-174. 
Holzapfel, E.A., M.A. Mariño, and J. Chávez-Morales. 1986. Surface irrigation optimization models. J. Irrig. Drain. Eng. ASCE 112:1-19.

Holzapfel, E.A., A. Valenzuela, M.A. Mariño, and F. Díaz. 1988. Comparison of infiltration measuring methods for surface irrigation. J. Irrig. Drain. Eng. ASCE 114:130-142.

Hsiao, T., P. Steduto, and E. Fereres. 2007. A systematic and quantitative approach to improve water use efficiency in agriculture. Irrig. Sci. 25:209-231.

Ibarra, M. 2004. Análisis de riego por surco en frutales. 180 p. Tesis Ingeniero Civil Agrícola. Universidad de Concepción, Facultad de Ingeniería Agrícola, Chillán, Chile.

Khan, S., R. Tariq, C. Yuanlai, and J. Blackwell. 2006. Can irrigation be sustainable? Agr. Water Manage. 80:87-99.

Kumar, R., and J. Singh. 2003. Regional water management modelling for decision support in irrigated agriculture. J. Irrig. Drain. Eng. ASCE 129:432-439.

Lazarovitch, N., A.W. Warrick, A. Furman, and D. Zerihun. 2009. Subsurface water distribution from furrow described by moment analyses. J. Irrig. Drain. Eng. ASCE 135:7-12.

Lehrsch, G.A., R.E. Sojka, and D.T. Westermann. 2000. Nitrogen placement, row, spacing, and furrow irrigation water positioning effects on corn yield. Agron. J. 92:1266-1275.

Popova, Z., D. Crevoisier, P. Ruelle, and J.C. Mailhol. 2005. Application of Hydrus2D model for simulating water transfer under furrow irrigation - Bulgarian case study in cropped lysimeters on Chromic Luvisol. p. 1-13. ICID $21^{\text {th }}$ European Regional Conference, Frankfurt, Germany. 15-19 May. International Commission on Irrigation and Drainage (ICID), New Delhi, India.
Rice, R.C., D.J. Hunsaker, F.J. Adamsen, and A.J. Clemmens. 2001. Irrigation and nitrate movement evaluation in conventional and alternate-furrow irrigated cotton. Trans. ASAE 44:555-568.

Sarwar, A., W.G.M. Bastiaanssen, and R.A. Feddes. 2001. Irrigation water distribution and long-term effects on crop and environment. Agr. Water Manage. 50:125140.

Scheaffer, R.L., y J.T. McClave. 1993. Probabilidad y estadística para ingeniería. 350 p. Grupo Editorial Iberoamérica S.A., México D.F., México.

Souza, F. 1981. Nonlinear hydrodynamic model of furrow irrigation. Ph.D. Thesis. University of California, Davis, California, USA.

Spurlock, F., 2000. Effect of irrigation scheduling on movement of pesticides to ground water in coarse soils: Monte Carlo analysis of simulation modelling. 255 p. State of California, Environmental Protection Agency, Department of Pesticide Regulation, Environmental Monitoring and Pest Management, Branch Environmental Hazards Assessment Program, Sacramento, California, USA.

Troiano, I., C. Garretson, C. Krauter, I. Brownell, and J. Huston. 1993. Influence of amount and method of irrigation water application on leaching of atrazine. J. Environ. Qual. 22:290-298.

Walker, W.R., and G.V. Skogerboe. 1987. Surface irrigation, Theory and practice. 386 p. Prentice-Hall, Englewood Cliffs, New Jersey, USA.

Zerihun, D., A. Sanchez, and K.L. Farrell-Poe. 2001. Analysis and design of furrow irrigation systems. J. Irrig. Drain. Eng. ASCE 127:161-167. 